\title{
3D MODELING OF RADIATION CONDITIONS AND DOSE RATES FOR PERSONNEL DURING DISMANTLING OF THE ROOF STRUCTURES OF THE SHELTER OBJECT
}

\author{
M. Pashynov, S.Pidbereznyy, S. Paskevych* \\ Institute for Safety Problems of Nuclear Power Plants NAS of Ukraine, Chornobyl, Ukraine
}

(Received September 25, 2018)

\begin{abstract}
The results of three-dimensional modeling of personnel work conditions in radiation-hazardous conditions of the "Shelter" object, carried out using the software complex HVRC VRdose, are presented. Estimations of dosing loads on personnel during the dismantling of a metal farm on the roof of the "Shelter" object are carried out. The obtained simulation data showed good convergence with the data obtained during the development of a working design for dismantling of this construction.
\end{abstract}

PACS: $29.85+\mathrm{c}, 28.41 . \mathrm{Te}, 28.90 .+\mathrm{i}$

\section{INTRODUCTION}

Objective: The "Shelter" object (OS) is a radiationdangerous object, on which a large volume of work on transformation into an ecologically safe system is carried out. An intermediate stage in this process is the construction of a new protective structure - the New Safety Confinement (NSC). During the period of existence of the NSC, it is necessary to dismantle structures that can collapse [1], as well as to remove hazardous accumulations containing nuclear fuel [2]. According to the Project Criteria [3], it is necessary to dismantle 18 unstable building constructions of the OS during the period of early dismantling and 10 structures of delayed dismantling.

Dismantling of unstable structures of the OS presupposes the presence of personnel in hazardous radiation conditions and in conditions where access to the work performance zones (WPZ) is complicated. The roofs of the OS are sloping, which makes it difficult to access operations sites (cutting, stroking, etc.). This leads to a high risk of employee injury, requiring increased attention to safety measures. Designing for dismantling should take into account all the negative factors and be based on optimal design solutions. The HVRC VRdose Planner, developed by the Institute of Energy Technologies (Norway), allows interpreting radiological information based on three-dimensional models of radiation-hazardous objects where human activity is planned. The HVRC VRdose Planner allows to create virtual models for each worker and recreate a detailed technological process of constructions dismantling with involving of personal.

In 2015, on the initiative of ChNPP, the design of a dismantling of one of the constructions, which is included in the list of "early" dismantling of unstable structures of the OS, has been developed. The Institute for Safety Problems of NPPs of the National Academy of Sciences of Ukraine (ISP NPP) developed the Safety Analysis Report [4].

Thus, verification of the results obtained by dismantling the farm using a software package is an opportunity to evaluate the suitability of the HVRC VRdose Planner for other design work to be performed.

\section{RESEARCH METHODS}

The HVRC VRdose Planner software allows to interpret radiological information based on threedimensional models of radiation-hazardous objects at which human work is planned. This software in its code has a mathematical tools that can count the accumulated doses of staff in real time.

The database of the software includes a virtual image of the staff. It is also possible to equip staff with different types of devices and simulate the movement of personnel on the specified routes.

The accuracy of calculations of the software complex has been repeatedly tested on real objects. In 2008, with the help of VRDose Planner, the possibility of unloading of spent nuclear fuel in the Andreev Bay [6] was estimated. Other $[7,8]$ also shows the use of this software package for simulating the accumulation of radiation doses by personnel.

HVRC VRDose software is a part of International Technical Assistance Project "Creation and implementation of Chernobyl NPP decommissioning Visualization Center" which was realized between the Cabinet of Ministers of Ukraine and the Government of the Norway Kingdom on cooperation in the field of Nuclear and Radiation Safety, Chernobyl NPP decommissioning and "Shelter" object transformation

\footnotetext{
*Corresponding author E-mail address: serpua@gmail.com
} 
into ecologically safe system. The developer of this software is the Institute of Energy Technologies from Norway.

\section{RESULTS OF THE CALCULATIONS}

To carry out the simulation of the dismantling of a metal farm on the roof of ChNPP Unit 4 at ISP NPP of the National Academy of Sciences of Ukraine the 3-dimensional model of the OS was created.

\subsection{Construction of the metal farm of the southern roof}

The southern roof of the OS is a complicated technical element. The roof is made up of flat panels and "brushes of brushes". The reason for the dismantling of these elements was the results of the analysis [5], which found that the probability of the failure of the "brushes of brushes" under extreme wind loads was extremely high and unacceptable. Therefore, in 2006 the stabilization of the southern roof (Stabilization Event No.8) was performed by combining flat shields and "brushes of brushes" in a single structural system with the help of a metal farm (Fig.1).

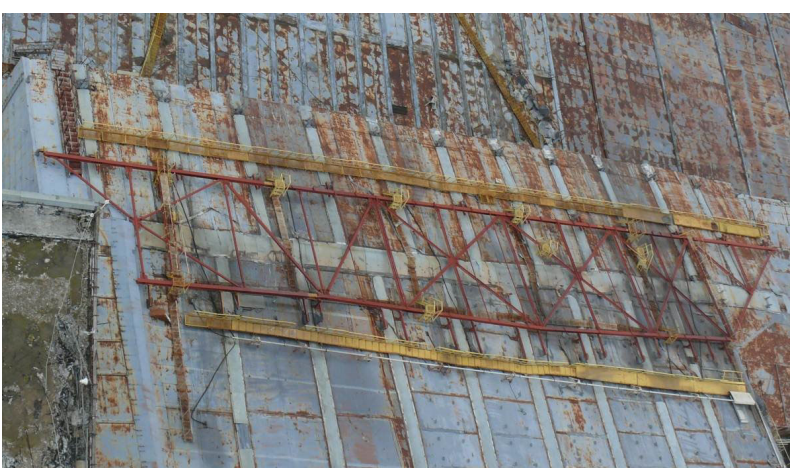

Fig.1. Metal farm on the roof of ChNPP Unit 4

\subsection{Modeling of radiation conditions in the dismantling zone of a metal farm}

To evaluate the radiation doses of personnel during radiation hazard work a document - SAR 301503.201.006-SAR /ISB NPP [4] - has been developed by the staff of the ISP NPP of the National Academy of Sciences. This document describes the entire process of dismantling, including the development of personnel paths at all stages of work and estimates the time during which all dismantling works will be performed.

HVRC VRDose allows to visualize the entire dismantling scenario for each of the metal farm fragments. However, if in the case of [4], conservative dose rates were used to calculate the personnel exposure, then in the HVRC VRDose there is a possibility to use the actual values of the DR on the southern roof of the OS.

Radiation survey of the southern roof was carried out in 2000, and the values of radiation doses using the coefficients were counted. The final view of the cartograms of dose rates, which is applied on the roof of the unit 4 for simulation, is shown in Fig.2.

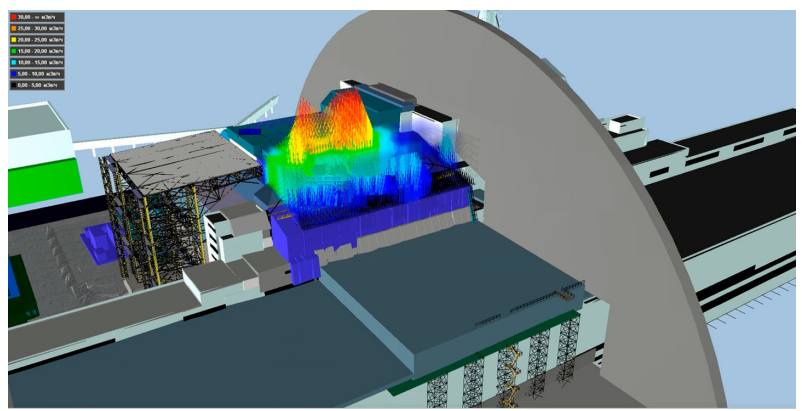

Fig.2. General view of the model for the dismantling of the southern roof modeling

To simulate the movement of personnel in the WPZ, a trajectory of personnel movement during radiation dangerous work is required, as well as the time for doing these works. With the initial data it is possible to calculate the accumulated dose that each member of the team will receive (Fig.3).

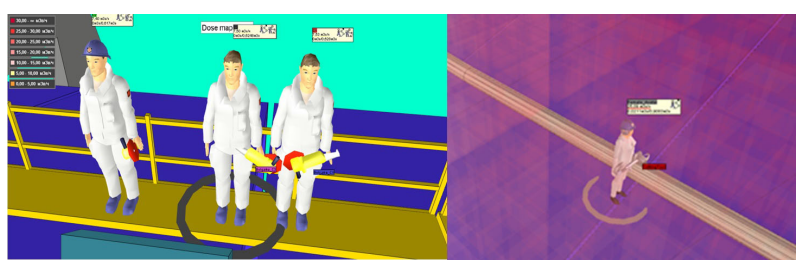

Fig.3. Virtual personnel images that will perform the work

\subsection{Modeling of the dismantling process of a metal farm fragment F1}

Farm fragment F1 is the first stage of dismantling of the metal reinforcement farm of the southern roof of the OS (Fig.4). According to [4], after conducting all preparatory work (laying cables with sockets, installing fixtures, etc.), dismantling work will be carried out under radiation-hazardous conditions. To dismantle farm fragment F1 on the southern roof, the following list of works will be carried out:

- Closure of flexible pipelines of the mobile dust suppression system (MDSS);

- Marking with paint of brackets C1-C4;

- Cutting by means of a mechanical cutting of fastenings of walking bridges to shields of OS roofing;

- Stroping of the nodes C1-C4;

- Cutting of brackets C1-C4, with the help of hand-held air-plasma cutter.

After simulating of all the parts of the dismantling of F1 fragment process, using [4] it is possible to verify the correspondence of the exposure doses to personnel. The simulation results are given in Table. 
Comparative analysis of the correspondence of radiation doses values

\begin{tabular}{|c|c|c|c|c|c|}
\hline $\begin{array}{l}\text { Type of } \\
\text { (item in SAR) }\end{array}$ & $\begin{array}{l}N_{\text {pers }} \\
\text { (number of } \\
\text { personnel) }\end{array}$ & $\begin{array}{l}\quad t_{p},[4], \mathrm{s} \\
\text { working time } \\
\text { according to } \\
\quad \text { SAR }\end{array}$ & $\begin{array}{l}E_{0},[4], \mathrm{mSv} \\
\text { DR } \\
\text { according to } \\
\text { SAR }\end{array}$ & $\begin{array}{l}t_{p}, \text { model, } \mathrm{s} \\
\text { work } \\
\text { according to } \\
\text { VRDose } \\
\text { Planner }\end{array}$ & $\begin{array}{c}E_{0}, \text { model, } \\
\text { mSv } \\
\text { DR } \\
\text { according to } \\
\text { VRDose } \\
\text { Planner }\end{array}$ \\
\hline \multirow{2}{*}{$\begin{array}{l}\text { Closure of flexible } \\
\text { pipelines of the MDSS, } \\
\text { the upper zone }(2.12) \\
\text { Point 1 }\end{array}$} & \multirow[t]{2}{*}{2} & \multirow[t]{2}{*}{690} & \multirow[t]{2}{*}{4.83} & \multirow[t]{2}{*}{690} & 2.53 \\
\hline & & & & & 1.85 \\
\hline \multirow{2}{*}{$\begin{array}{l}\text { Closure of } \text { flexible } \\
\text { pipelines of the MDSS, } \\
\text { the upper zone }(2.12) \\
\text { Point 2 }\end{array}$} & \multirow[t]{2}{*}{2} & \multirow[t]{2}{*}{690} & \multirow[t]{2}{*}{4.83} & \multirow[t]{2}{*}{690} & 2.85 \\
\hline & & & & & 2.58 \\
\hline \multirow{2}{*}{$\begin{array}{l}\text { Closure of flexible } \\
\text { pipelines of the MDSS, } \\
\text { the upper zone }(2.13) \\
\text { Point 3 }\end{array}$} & \multirow[t]{2}{*}{2} & \multirow[t]{2}{*}{648} & \multirow[t]{2}{*}{4.94} & \multirow[t]{2}{*}{648} & 3.8 \\
\hline & & & & & 3.55 \\
\hline \multirow{2}{*}{$\begin{array}{l}\text { Closure of flexible } \\
\text { pipelines of the MDSS, } \\
\text { the upper zone }(2.13) \\
\text { Point } 4\end{array}$} & \multirow[t]{2}{*}{2} & \multirow[t]{2}{*}{648} & \multirow[t]{2}{*}{4.94} & \multirow[t]{2}{*}{648} & 4.48 \\
\hline & & & & & 3.78 \\
\hline $\begin{array}{l}\text { Marking with paint of } \\
\text { bracket C1 }(2.10)\end{array}$ & 1 & 120 & 0.4 & 122 & 0.24 \\
\hline $\begin{array}{l}\text { Marking with paint of } \\
\text { bracket C2 }(2.10)\end{array}$ & 1 & 120 & 0.4 & 102 & 0.25 \\
\hline $\begin{array}{l}\text { Marking with paint of } \\
\text { bracket C3 }(2.9)\end{array}$ & 1 & 155 & 0.494 & 150 & 0.578 \\
\hline $\begin{array}{l}\text { Marking with paint of } \\
\text { bracket C4 (2.9) }\end{array}$ & 1 & 155 & 0.494 & 152 & 0.74 \\
\hline \multirow{2}{*}{$\begin{array}{l}\text { Cutting of fastenings of } \\
\text { walking bridges of upper } \\
\text { zone of the farm }(2.7)\end{array}$} & \multirow[t]{2}{*}{2} & 720 & 4.92 & 680 & 1.62 \\
\hline & & (every) & (every) & 670 & 1.5 \\
\hline $\begin{array}{l}\text { Cutting of fastenings of } \\
\text { walking bridges of lower } \\
\text { zone of the farm }(2.8)\end{array}$ & 1 & 823 & 4.18 & 706 & 2.72 \\
\hline \multirow{2}{*}{$\begin{array}{l}\text { Stroping of the node } \\
\text { C1 }(2.14-2)\end{array}$} & \multirow[t]{2}{*}{2} & \multirow[t]{2}{*}{720} & \multirow[t]{2}{*}{1.85} & 678 & 1.26 \\
\hline & & & & 682 & 1.42 \\
\hline \multirow{2}{*}{$\begin{array}{l}\text { Stroping of the node } \\
\text { C2 }(2.14-4)\end{array}$} & \multirow[t]{2}{*}{2} & \multirow[t]{2}{*}{720} & \multirow[t]{2}{*}{2.16} & 685 & 1.74 \\
\hline & & & & 716 & 1.78 \\
\hline Stroping of the node & 2 & 720 & 4.81 & 683 & 3.9 \\
\hline C3 $(2.14-1)$ & & & & 693 & 3.43 \\
\hline Stroping of the node & 2 & 720 & 4.36 & 692 & 2.9 \\
\hline C4 $(2.14-3)$ & & & & 696 & 2.67 \\
\hline Cutting of bracket & 2 & 1080 & 2.36 & 1045 & 2.18 \\
\hline C1 $(2.18-1)$ & & & & 1044 & 1.93 \\
\hline Cutting of bracket & 2 & 1080 & 2.84 & 1047 & 2.28 \\
\hline C2 $(2.18-2)$ & & & & 1049 & 2.83 \\
\hline Cutting of bracket & 2 & 1080 & 4.14 & 1045 & 6 \\
\hline C3 $(2.20-1)$ & & & & 1049 & 5.3 \\
\hline Cutting of bracket & 2 & 1080 & 4.14 & 1054 & 4.4 \\
\hline $\mathrm{C} 4(2.20-2)$ & & & & 1053 & 3.9 \\
\hline
\end{tabular}

\subsection{Simulation results analysis}

The simulation results show that for point 2.9 marking for the brackets $\mathrm{C} 3, \mathrm{C} 4$ there is an excess of the radiation dose calculated in [4]. According to [4], the value of the $\mathrm{DR}$ in calculation was $-18 \mathrm{mSv} / \mathrm{h}$.
During the simulation, there were areas where the $\mathrm{PD}$ reached the values of $21 \mathrm{mSv} / \mathrm{h}$. Such deviations from the design values can lead to receiving higher radiation doses of personnel.

For the $\mathrm{C} 4$ bracket, the accumulated dose is $33 \%$ 
higher than that of [4]. Similar effect is observed with the final cutting of brackets C3 and C4. The personnel at the time of performing these works is in higher radiation load, compared with [4].

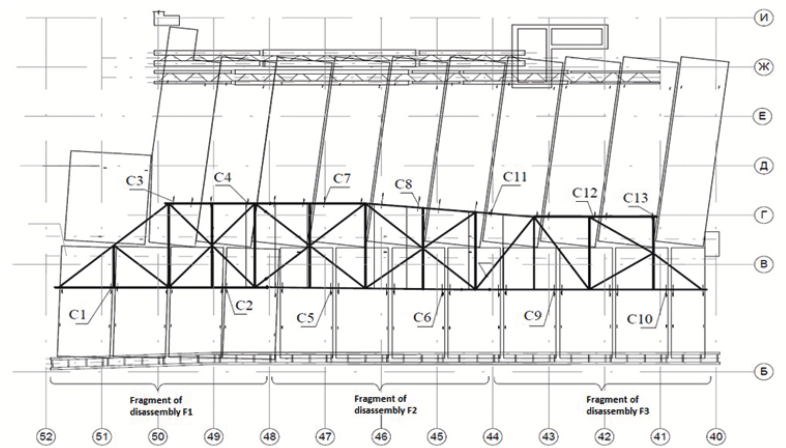

Fig.4. Places of work during dismantling of metal farm

Using a detailed map of radiation contamination, it was possible to obtain a more accurate estimation of radiation doses of personnel performing radiationhazardous work. The obtained values for some of the processes exceeded the values of radiation doses, which were calculated conservatively. With a more detailed understanding of the radiation situation at the site of work, exist an opportunity to increase the level of personnel protection and to reduce the time spent in high radiation fields.

\section{CONCLUSIONS}

Using the HVRC VRDose software calculations of radiation doses of personnel during the performing of the basic operations for the dismantling of a metal farm and comparisons with SAR were carried out. The data obtained using the software is well correlated with the project data. For operations that are similar in radiation conditions - exposure levels are the same. However, the software package allows for more accurate modeling of radiation doses in space, that is why for certain operations the radiation levels are $20 \ldots 30 \%$ higher than the design values. This is explained by more precise estimations of radiation conditions compared to calculations performed by conservative methods. In case of using of real radiation conditions, the dose rate at the site of the work is not a constant, but a dynamic value, thus the total accumulated over the entire duration of the work radiation dose is calculated with greater accuracy. With a more detailed understanding of the radiation situation at the site of work, it is possible to increase the level of personnel protection and reduce the time spent in high radiation fields.

The HVRC VRDose software package is a convenient tool for calculating estimated radiation doses in radiation-hazardous conditions, thus allowing for the development of several alternatives for the performance of works, it enables to optimize the process of work performance and personnel behavior in radiation-hazardous conditions.

\section{References}

1. Report on the reassessment of the composition of unstable OS structures subject to "early" dismantling // SIP 09-2-001 NI 03 RPT 03705.

2. The strategy of re-inventing the "Shelter" object. 2001.

3. Design criteria and requirements for the NSC infrastructure for dismantling the unstable structures of the «Shelter» object SIP 03100307 DCR 00103 // SIP PMU, 2008.

4. Reconstruction of the "Shelter" object of the Chornobyl NPP in connection with the dismantling of the southern roof reinforcement of a metal farm, SAR 301503.201.006 // ISP NPP NASU, 2016.

5. Integrated report of stabilization measures. Package A "Civil Engineering", Task A1 "Integration and mobilization of stabilization and screening projects (WBS A01 14100 - Doc. 1.6a, 15.09.99)// ICC (MK)JV; Kyiv - Chornobyl, 1999.

6. K. Chizhov, M. K. Sneve. 3D simulation as a tool for improving the safety culture during remediation work at Andreeva Bay // Society for Radiological Protection, 2014.

7. I. Szoke, T. Johsen. Human-centred radiological software techniques supporting improved nuclear safety // Nuclear Safety and Simulation. 2013.

8. Michael N. Louka, Tom-Robert Bryntesen. Comprehensive support for nuclear decommissioning based on 3D simulation and advanced user interface technologies // Journal of Nuclear Science and Technology. 2017. 


\title{
3D-МОДЕЛИРОВАНИЕ РАДИАЦИОННЫХ УСЛОВИЙ И ДОЗ ОБЛУЧЕНИЯ ПЕРСОНАЛА ПРИ ДЕМОНТАЖЕ КОНСТРУКЦИЙ КРОВЛИ ОБЪЕКТА "УКРЫТИЕ"
}

\author{
М. Пашинов, С. С. Подберезный, С. А. Паскевич
}

Представлены результаты тремерного моделирования условий работы персонала в радиационно опасных условиях объекта "Укрытие", выполненного с помощью программного комплекса HVRC VRdose. Оценены дозовые нагрузки на персонал при выполнении работ по демонтажу металлической фермы на кровле объекта "Укрытие". Полученные данные моделирования показали хорошую сходимость с данными, которые были получены при разработке рабочего проекта демонтажа этой конструкции.

\section{D-МОДЕЛЮВАННЯ РАДІАЦІЙНИХ УМОВ I ДОЗ ОПРОМІНЕННЯ ПЕРСОНАЛУ ПРИ ДЕМОНТАЖУ КОНСТРУКЦЙ ПОКРІВЛІ ОБ'ЄКТА "УКРИТТЯ"

\author{
М. Пашинов, С. С. Підберезний, С. А. Паскевич
}

Представлені результати тривимірного моделювання умов роботи персонала у радіаційно небезпечних умовах об'єкта "Укриття", виконаного з допомогою програмного комплекса HVRC VRdose. Оцінені дозові навантаження на персонал при виконанні рабіт по демонтажу металевої ферми на покрівлі об'єкта "Укриття". Отримані дані моделювання показали добру узгодженість з даними, які були отримані при розробці робочого проекта демонтажу цієї конструкції. 